\title{
土砂粒子の運動の解析を基礎とした 河床波の形成過程シミュレーションの試み
}

\author{
関根正人 1 \\ ${ }^{1}$ 正会員 工博 早稲田大学教授 理工学部土木工学科（广 169-8555 東京都新宿区大久保 3-4-1)
}

\begin{abstract}
砂漣や砂堆として知られている河床上に形成される微地形の形成機構について，その従来研究を振り返ると， その多くが安定・不安定解析に代表されるような保存則に基づく解析であり, 個々の土砂粒子の移動特性を陽に 反映させた解析はほとんどなされていない. 本研究では，これまで著者らが開発してきた土砂運動の解析モデル (いわゆる Saltation Model) を基䃈として, これに流れ場の予測モデルを加えることで, 新たな数值シミュレー ションモデルを構筑している。これは，個々の土砂粒子が河床から離脱すれば浸食が，その粒子が新たな位置に 停止すればその位置に堆積が, それぞれ一粒径分だけ生じる，という河床変動の基䃈的過程を忠実に反映したも のであり，この集積として河床上微地形が形成・発達していく過程を数值模擬しょうとするものである. 本研究 はこのような試みの第一歩となるものであり,これにより河床上の微小な凹凸が砂堆規模の河床波へと発達し ていく過程を再現することができ,こうした河床波形成のメカニズムに関する有益な知見が得られたと考える.
\end{abstract}

Key Words : sand waves, saltation model, numerical simulation, pick-up rate, deposition rate

\section{1. 序論}

平坦な河床を初期条件として移動床実験を行うと, そ の河床は必ずしも平坦床のままではなく，設定した水 理条件や土砂の特性によっては微小な擾乱が河床上に 生み出され，それが成長を遂げるとやがては砂漣や砂 堆として知られようなスケールの河床波にまで発達す ることが知られている．このような河床波が形成され る過程については，これまでに数多くの研究がなされ， その成果も一応の体系化を見ている1).これらによる と，河床上の流砂が空間的に不均衡となることで河床 波が生じ，その発生原因としては，(1) 河床自体がもつ 微小な凹凸，(2) 水流の持つ種々のスケールの乱れ，(3) 砂粒子の運動の不規則性, などが挙げられると指摘さ れている.これらの従来研究を調べてみると，そのほ とんどが平衡流砂量式と土砂の収支式 (いわゆる Exner の式) とに依拠した解析であり，Kennedy ${ }^{2}$ による不安 定解析がその例である。 その後, 数々の研究がなされ る中で, 最近, 檜谷・道上 ${ }^{3)}$ が, 河床に作用するせん断 力に擾乱を与えることで, 流砂量を空間的に不均一と すると, 時間の経過とともに砂堆と判断される河床波 が形成されるというシミュレーション結果を報告して おり，新たな試みとして興味媣い，ただし，せん断力 の值に加えられた擾乱成分の原因あるいは規模におい て曖昧さが残されている．また，これを含めた従来の 研究に共通の問題点として「流砂の非平衡性」の影響 が明確な形で反映されていないことがあげられる。こ
のような問題を解消する方法としては, 現象の本質で ある個々の土砂粒子の運動にまで立ち返って解析する ことが考えられるが，このようなアプローチはこれま でほとんど見られず，わずかに中川・辻本 $\left.{ }^{4}\right)$ が土砂運動 に関する Stochastic model を適用して行った研究があ るばかりである．このような現状は，河床波の発生要 因の (1) および (3) を, 合理的に解析に取り入れること が容易でなかったことに起因するものと考えられる.

こうした現状に鑑みて, 関根・浅田 $\left.{ }^{5}\right)$ ならびに関根・ 北川吕は,これまでに開発してきた「土砂粒子の運動 解析のシミュレーション・モデル」(以下, “Saltation Model” と呼ぶ(7),8),9)を基礎として, 河床波の形成過 程を個々の土砂移動の集積として数值模擬することを 試みている.これらの研究において提示されたモデル は, 本論文で説明する解析モデルの雊形と位置づけら れるものであり, 次章で説明する解析方法に関わるア イデアのいくつかは既にそこに盛り込まれていた。し かし，流れ場をかなり単純化し，簡潔に取り扱ったた め, 河床上の凹凸が砂漣や砂堆の規模の河床波にまで 発達することはなく，その前段階に当たる河床上に組 織的な凹凸が形成される過程 (後述する河床波の初期発 達過程) までの解析に止まっていた. このようなことを 考慮して, 本研究では, 土砂移動に関する「Saltation Model」と, 鉛直二次元流れを数值解法する「流れ場の モデル」とをカップリングした新たな解析モデルを開 発することとし，特に後者をこれまでのもの ${ }^{5), 6) よ り ~}$ 一般的かつ合理的なものへと拡張している.これによ 


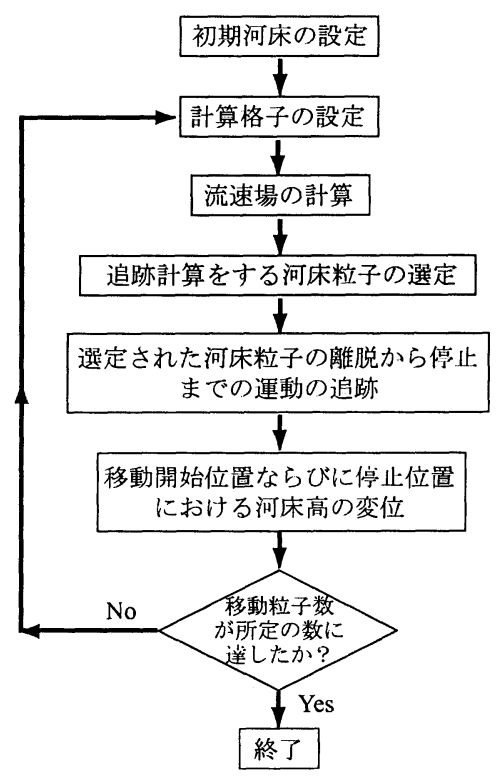

図-1 計算のフローチャート

り，河床上の凹凸が砂漣あるいは砂堆規模の河床波に まで発達する過程を数值的に再現し，その形成のメカ ニズムに関わる興味深い知見を得ることができた．な お，ここで基礎とする Saltation Model は，土砂の河床 からの離脱から停止までの一連の掃流運動を運動方程 式に基づき追跡するものである.この解析によって再 現される典型的な運動は，いわゆる Saltation(跳躍) と して知られるものであるが，これは十分に発達した段 階での運動であって, 初期移動あるいは停止直前の運 動では，その跳躍の規模が極端に小さくなり，たとえ ば滑動形式の運動のように絶えず河床と接触しながら 移動する軌跡をも再現することができる．このモデル の妥当性の検証を含めた詳細に関しては, 別論文 ${ }^{8), 9)}$ において説明済みであり, 詳しくはそちらを参照され たい.

\section{2. 数值解析モデルの開発}

\section{(1) 解析モデルの概要}

本研究では, 河床上の微地形である河床波の形成過 程を河床表面を構成する個々の土砂粒子群の高さの時 空間的変化として数值的に模擬することを試みるとと もに, この形成機構の力学的理解を深めることを目的 とする.ここで提示する解析モデルの開発に当たって は，いくつかの近似に基づく簡略化を行っている．鉛 直二次元の場を想定していることなどがその一例であ る.これは, 三次元の場で同様の解析を行うことは十
分可能であるものの, 莫大な計算量を必要とするなど 難点も多く, 今後に向けての第一歩として開発・実施す るモデルとしては必ずしも望ましくないと判断したた めである.そして，このような取り扱いにより，計算 に要する負荷を飛躍的に軽減することができる. 現象 の定性的な理解という観点に立てば，この取り扱いが 問題となることはないと考えられるが，例えば河床微 地形の形成の初期段階においては, 河床面の凹凸の三 次元性の影響が相対的に重要であることも予想される. こうした影響については, 今後取り組むべき課題とし， ここでは敢えて考慮することはしない。このほかにも いくつかの簡略化を行っているが, これについては後 述する.

本解析モデルは，大きく分けて「流れ場の解析モデ ル」とその場における「河床粒子の離脱・流送・停止 といった運動追跡モデル」とからなる. それぞれのモ デルの詳細については, 次節以降で説明することにし, ここでは, 解析モデル全体の構成と考え方について簡 単に記すことにする. 解析対象領域については, 次の ように設定する. まず, 流下方向には, 河床構成材料 の粒径 D の 2048 倍の規模の区間をとることにし，こ の上下流端の断面ではいわゆる周期境界条件を適用寸 ることにした. なお,この計算領域の規模については, これを半分あるいは 3 倍にした計算も行っており, こ の計算規模が結果に及ぼす影響についてもあわせて検 討することにした. また, 鉛直方向には, 時空間的に変 動する河床面からその上方に位置する水面までの区間 をとることにする. 数值計算の主な流れは図-1 に示す 通りであり, 以下に簡単な説明を加えておく，(1) 任意 の河床面形状に対して, 後述するような計算格子を設 定し, 格子点上の流速成分を算定するとともに, 水面 形状を求める. (2) 着目すべき河床粒子を任意に選定し た後, この粒子の河床からの離脱・流送・停止の全過程 を数值的に追跡する. この際, 粒子が移動している点 において評価された流速の作用を受けることはいうま でもない. また, 跳躍運動とはいえ河床と絶えず衝突 を繰り返しながら運動を継続していくため, その運動 軌跡は河床の凹凸の状態の影響を陽に受けたものとな る. なお, 以上 2 点の取り扱いによって流砂の非平衡 性の影響を考慮することができる. (3) 選定された粒子 が離脱できずに河床に止まる場合には，新たな粒子を 選定し直し，その運動を解析する. (4) 粒子の移動が生 じると, 移動開始点の河床が一粒径分だけ低下し, 停 止点のそれが一粒径分だけ上昇することになる.そこ で, 選定粒子の運動の追跡が完了した時点で, 流れに とっての下方境界である河床面形状を変化させる．(5) 次に, 更なる粒子の運動の追跡に当たっては, このよ うな河床形状の変化が流れ場に及ぼす影響を適宜反映 
させていくことが望ましいため, 計算格子の再設定を 行い, 流れ場の計算を再度行うことで流速データを更 新していくことにする. 以上のようにして，本解析で は, 流れ場の計算と粒子の運動の追跡計算とを交互に 行い, 河床形状の時間発達の数值模擬を試みることに する. なお，本解析における初期河床としては，いわ ゆる平坦床を想定しているが, 実験時の観察などから 平坦床といえども粒径スケールの凹凸があり，微視的 に捉えるならばランダムな成分をもつことが知られて (るる). そこで，ここでも前論文 ${ }^{8)}$ に倣って，一定勾配 で傾斜した平面の上に, 標準偏差を粒径の $1 / 3$ とした 正規乱数を用いて生起される粒径スケールの凹凸を重 ね合わせることで, ランダム河床を生成し，これを初 期河床としている.

\section{（2）流れ場の解析}

流れ場の計算では，前述の計算対象領域を計算格子 網で覆いつくし, 格子点における流速べクトルと各鉛 直断面における水位とを求める. 計算格子の生成に当 たっては，次のように考えることにする. 本研究で対 象とする流れ場は, その底面境界形状が粒径スケール の凹凸を伴っていることに加えて，この凹凸が時間と ともに発達していくことになるため, この底面境界は 通常の数值計算で対象とされるものに比べて遙かに不 規則で複雑なものとなる.このため, 粒径あるいはそ の数倍程度の規模の計算格子を採用すると, それだけ で膨大な計算負荷がかかるばかりでなく, 解の安定性 を損なう恐れがある. そこで, 本解析では, 流下方向 の格子点間隔を粒径よりはある程度大きなもの (後述す る計算例では, これを粒径の 16 倍) とし, 格子スケー ルで平滑化された河床面に対して流れ場を評価するこ とにした.これは現時点で使用しうる計算機の処理能 力などから決まってくる限界でもあり, 本解析で行った 簡略化のうち影響の最も大きなものといえよう. 水深 方向の格子については, 河床面付近ほど流速の変化が 大きいことを考慮して, 河床面からある決められた格 子点 (計算例では 5 点目) までは粒径の半分の間隔で格 子を配置し, それより上の水面までの範囲には同数 (計 算例では 20 個) の格子点を, 水深に応じて決まる一定 の間隔で配置することにした.このように, ここで設 定した計算格子は, 流下方向には一定の間隔に, 水深 方向には河床面付近で密に, それより上方では粗にな るように，それぞれ配置されていることになる.

さて，ここでの流速場の解析に関しては，その手法 としては非定常計算によるものとし, 各時刻における 河床粒子群の配列状態に見合った定常解が得られるま で計算を続けることにする. また，この計算は着目粒 子の運動の追跡に先立って行うものとし, 粒子の移動
中には流れ場が変化することはないものとした．実際 には，ある河床粒子が移動を開始したり，移動粒子が 河床に停止したりすると, それに伴って河床構成粒子 群の配列が変化するために, 河床面近傍を中心とした 流速場の変化が生じ, この定常解と厳密に一致する流 れが生じているわけではない.しかし, 土砂の粒径に 比べて比較的大きな計算格子を用いていること, 流れ 場が境界形状の変化に対して比較的速やかに応答し境 界形状に見合った定常解に達しうる(擬似定常の仮定) こと, などの理由から, 近似的にこのような取り扱い をすることにした，ただし，より㛜密に考えるならば, 粒子が移動している最中にも水流と粒子との間で行わ れる運動量交換のために, 流速場は時々刻々変化する ことが考えられる.このような流体と粒子との相互作 用の影響については, 掃流力が比較的大きな条件にお いて顕著に現れるものと考えられるが，ここで対象と する現象は，土砂の移動がそれほど活発ではなく，個々 の粒子が掃流砂の形式をとって移動するような比較的 小さな掃流力範囲におけるものであるため, このよう な影響を無視することはそれほど大きな問題とはなら ないと判断している. さらに, 将来, 浮遊形式の移動に ついても解析の対象とする場合には，平均流に加えて 流速の乱流成分まで評価することが不可欠となり, 何 らかの乱流モデルを導入して流速の時間変動まで評価 することが不可欠となる.こうした点については次の 課題とする.

このような前提に立って計算を行う上での支配方程 式を以下に示す.ここでは, 圧力の静水圧分布近似を適 用する. そのため, 水梁方向の運動方程式については, これを解くことを省略する. また, 計算に当たっては, 水深方向 $(z$ 軸方向) に同数の格子点を配置するものの, 格子間の $z$ 方向の間隔 $d z$ が水深方向のみならず流下方 向 $(x$ 軸方向 $)$ にも変化する不均等メッシュを用いるた め, ここでは, 元々の方程式群を一般座標 $(\xi, \eta)$ 系に書 き換えた後, 簡単な変形を施した次式を支配方程式と して解くことにする.

$$
\begin{gathered}
\frac{\partial U}{\partial \xi}+\frac{\partial W}{\partial \eta}=0 \\
\frac{\partial u}{\partial t}+U \frac{\partial u}{\partial \xi}+W \frac{\partial u}{\partial \eta}=-g \xi_{x} \frac{\partial H}{\partial \xi} \\
+J \frac{\partial}{\partial \xi}\left[\frac{\nu_{t}}{J}\left(q_{11} \frac{\partial u}{\partial \xi}+q_{12} \frac{\partial u}{\partial \eta}\right)\right] \\
+J \frac{\partial}{\partial \eta}\left[\frac{\nu_{t}}{J}\left(q_{21} \frac{\partial u}{\partial \xi}+q_{22} \frac{\partial u}{\partial \eta}\right)\right] \\
U=\xi_{x} u+\xi_{z} w ; W=\eta_{x} u+\eta_{z} w
\end{gathered}
$$

ここに, $H$ は水位であり, また, 式中に現れる Jacobian と metrics は，以下のように定義される.すなわち， 
$1 / J=x_{\xi} z_{\eta}-x_{\eta} z_{\xi}, \xi_{x}=J \cdot z_{\eta}, \quad \eta_{x}=-J \cdot z_{\xi}, \xi_{z}=$ $-J \cdot x_{\eta}, \eta_{z}=J \cdot x_{\xi}, x_{\xi}=\partial x / \partial \xi, x_{\eta}=\partial x / \partial \eta, z_{\xi}=$ $\partial z / \partial \xi, z_{\eta}=\partial z / \partial \eta, q_{11}=\xi_{x}^{2}+\xi_{z}^{2}, q_{12}=q_{21}=\xi_{x} \eta_{x}+$ $\xi_{z} \eta_{z}, q_{22}=\eta_{x}^{2}+\eta_{z}^{2}$ である. なお，ここでの解析の場 合には, $\xi_{z}=0, \xi_{t}=0$ となる. また, 乱流拡散係数 $\nu_{t}$ は, $\zeta=z / h$ の関数として $\nu_{t}=\kappa u^{\star} h \zeta(1-\zeta)$ により与 えることにする. ここに, $h$ は水深, $u^{\star}$ は摩擦速度， $\kappa$ はカルマン定数である.

これらの方程式の離散化ならびに解法に当たっては, スタッガード格子システムを採用するとともに, 時間微 分に関してはAdams-Bashforth Schemeを,また式 (2) の移流項の扱いには CIP 法10)を用いている. また, 境 界条件としては, 上下流端で周期境界条件を, 水面では Kinematic Boundary Condition を, 底面では Non-Slip Condition を，それぞれ与えることにする.

\section{(3) 土砂粒子の運動の解析}

ここでは, 粒子の河床からの離脱に始まり, 水流中 を掃流砂として移動し, やがては河床に停止するまで の一連の運動を, 運動方程式の数值解法を通じて追跡 する.この運動の解析には，著者らがこれまでに開発し てきた Saltation model ${ }^{8), 9)}$ を適用する.ここでの計算 の概略は次の通りである。まず最初に，運動を追跡す る着目粒子を一様乱数を用いて無作為に選定する. 次 に，選定された河床粒子に対して，これがその隣接す る粒子群の中から離脱可能であるかを運動方程式に基 づいて力学的に判定する.もし，この粒子の離脱が不 可能であると判断されたならば，粒子の選定をやり直 し, 同様の判定を行う。 もし, 離脱可能であるならば, 同一の方程式を引き続き解くことでその一連の運動を 追跡する. この際, 河床面を構成する他の粒子群との 接触・衝突を繰り返すため, その判定を絶えず行うと ともに，これが生じる場合には衝突事象を力学的かつ 合理的に取り扱うモデル8)を適用してこれを処理するも のとした.さらに、このような接触・衝突を伴う運動 (いわゆる Successive Saltation) を経て, 移動土砂粒子 はやがて再び河床粒子群の中に捕捉され，停止 (すなわ ち堆積)することになる．実験時に撮影した Successive Saltationのビデオ画像の解析によれば，移動粒子の多 くは, 河床粒子間に形成されている凹凹に取り込まれ, この間で衝突を繰り返すことでそのエネルギーを減衰 させ，そこから抜け出ることができずに停止する場合 がほとんどであることが理解されている8). そこで，こ こでも，前報で開発した停止モデル8)を適用し，その処 理を行うことにした．なお，特定の粒子に関する一連 の運動の追跡は，この停止をもって終了となる.

このような追跡と連動して, 河床面高さに関する処 理を行う.すなわち, 河床からの粒子の離脱が完了し
た時点でその河床高を一粒径分低下させ，また，移動 粒子が河床に停止した時点でその位置の高さを一粒径 分上昇させることにする.この集積として河床変動が 進行していくことになる.

土砂粒子の運動を支配する方程式は, 式 (4)に示す通 りであり，これを時間軸方向に離散化し，Runge-Kutta 法により解くことで, 微小時間毎の土砂粒子の座標お よび速度べクトルが求められることになる.

$$
\begin{aligned}
\rho \sigma_{s} V & \frac{\partial \overrightarrow{u_{p}}}{\partial t}=\rho\left(\sigma_{s}-1\right) V \vec{g}+\rho V \frac{\partial \overrightarrow{u_{f}}}{\partial t} \\
& +\frac{1}{2} \rho C_{D} A\left|\overrightarrow{u_{r}}\right| \overrightarrow{u_{r}}+\rho V C_{M} \frac{\partial \overrightarrow{u_{r}}}{\partial t} \\
& +\frac{1}{2} \rho C_{L} A\left(\left(u_{r x}^{2}\right)_{T}-\left(u_{r x}^{2}\right)_{B}\right) \vec{e}
\end{aligned}
$$

ここに， $\overrightarrow{u_{p}}$ は土砂粒子の移動速度ベクトル， $\overrightarrow{u_{f}}$ は作用 流速ベクトルである. また，重力加速度べクトル $\vec{g}$ は 河床の平均傾斜角を $\theta$ として $(g \sin \theta,-g \cos \theta)$ であり, $\vec{e}$ は $(0,1)$ で表される単位べクトルである. また, 揚力 項の中に現れる $u_{r x}$ は相対速度ベクトル $\overrightarrow{u_{r}} \equiv \overrightarrow{u_{p}}-\overrightarrow{u_{f}}=$ $\left(u_{r x}, u_{r z}\right)$ の $x$ 方向成分であり, 粒子の頂部 $T$ と底部 $B$ において評価される. $\rho$ は水の密度, $\sigma_{s}$ は土砂の比 重, $V$ は体積, $A$ は投影面積, $C_{D}, C_{L}$ および $C_{M}$ は抗 力係数, 揚力係数および付加質量係数である ${ }^{9)}$. 式中の $\overrightarrow{u_{f}}$ については, 流れ場の計算の際に設定された格子点 における值が求められているに過ぎないため, ここで はこの離散的な值に基づき, 各瞬間の粒子位置に対応 する值を線形補間によって求め, これを与えることに した.

なお，本モデルにおいては，同時進行する複数粒子 の運動を並行して追跡することを省略している．この ことは，移動粒子同士の干渉を無視し，本来同時に生 じることが予想される複数の土砂粒子の移動をそれぞ れ独立に追跡することを意味する.ここで対象とする 掃流力の範囲内ではこうした粒子間干涉の影響は無 視しても差し支えない程度であると考えられるが，時 間軸に関して言えば，ある数の粒子の運動の解析が終 了した時点で, 初期河床の状態からどのくらいの時間 が経過しているかを, 明確に定められないという問題 点を抱えている. そこで, ここでの解析結果は, 初期 河床から「“ $n$ ”個の粒子の追跡が完了した時点」とい う尺度で時間発達を説明することになる。

\section{3. 数值解析結果とその考察}

本章では, 一例として次のような条件下で行われた数 值実験結果を示しながら，河床波の形成過程についての 考察を試みる. 主な計算条件は, 無次元掃流力 $\tau^{\star}=0.08$, 粒径 $D=1.0(\mathrm{~mm})$, 水深 $h=13.2(\mathrm{~cm})$, 平均河床勾配 $i_{o}=1 / 1000$, 単位幅流量 $q=800\left(\mathrm{~cm}^{3} / \mathrm{sec} / \mathrm{cm}\right)$ などで 
ある．また，計算時間刻みを $d t=0.005$ (sec.) とし，衝 突事象を特徵づけるパラメータである反発係数を従来 通りの值である $e=0.65$ とした.

まず，図-2には，河床形状の時間発達過程を示した． 本論文では，延べ 100000 個の河床粒子の運動が完了す るまでの過程を対象としており，図中に示された $n$ の 值が，その時点で追跡を完了した粒子個数を表してい る.ここでは，一連の河床形状の時間変化を図-2(a) お よび (b)に分けて整理しており，一部の波形について は比較のため重複して示してある。また，この図では， 河床形状の時間変化を理解しやすくするため, 初期河床 勾配 $i_{0}$ で傾いた斜面が水平面となるように表示すると ともに，これを $z$ 軸方向に拡大して示している．また， 図-3には, 各段階 $n$ (言い換えれば各時刻)における河床 高 $z_{B} / D$, 水面高 $H / D$ ならびに摩擦速度比 $u^{\star} / u_{\mathrm{o}}^{\star}$ の縦 断変化とあわせて, 河床粒子の無次元離脱率 (Pick-up rate) $P_{s}^{\star}$ と堆積比率 $P_{\text {dep }}$ の空間分布を示してある.こ こに, $u_{o}^{\star}=\sqrt{g h i_{o}}$ である. なお, $P_{s}^{\star}$ と $P_{\text {dep }}$ は, 得ら れた河床形状に対して別途行われた再現計算により求 めるものとし，上流側の粒子から順にその運動を追跡 することで蓄積したデータを統計処理することにより 評価した． $P_{s}^{\star}$ の算定に当たっては，ここでは次式のよ うに考えることにする.

$$
P_{s}^{\star}=\sqrt{D / R g} \times\left(p_{o} / T_{\text {rest }}\right)
$$

ここに, $p_{o}=\left(N_{m} / N_{T}\right)$ であり, $T_{\text {rest }}$ は Rest period, $N_{m} / N_{T}$ は河床として想定した全粒子数に対する離脱 ・ 流送された粒子数の割合を表す.この再現計算では, 河 床表面を構成する全ての粒子に対して河床からの離脱 の可能性を判別し，離脱・流送される粒子については, 初期位置から隣接する下流側の粒子を乗り越え, 粒径 を越える距離にわたる移動を完了するまでに要した時 間を $T_{\text {rest }}$ と定義している. 一方， $P_{\text {dep }}$ については，相 対的に見た堆積の生じ易さを示す指標として，離脱し た全粒子数に対する任意点に停止・堆積した粒子数の比 率として定義する，ここでの計算では，移動した全て の粒子が停止するまでの運動を追跡しているため, 全 粒子についての追跡が完了した時点で移動粒子群の停 止位置に関する頻度分布が求められ，これを相対的な 比率に直すことで $P_{d e p}$ を求めている.このような定義 のため, この值が大きいほど停止・堆積が生じやすい ことを表すものの, この比率を離脱率と直接比較して, 堆積・浸食の議論をすることはできない.

さて, この図-2 および図-3, さらには図には示し切 れない数值実験時の観察結果などを基に, 河床波の形 成過程について考察を加えることにする.ここでは，こ の形成過程を初期発達過程とそれ以降の過程とに分け て考えるものとし，このようにすることで形成機構の
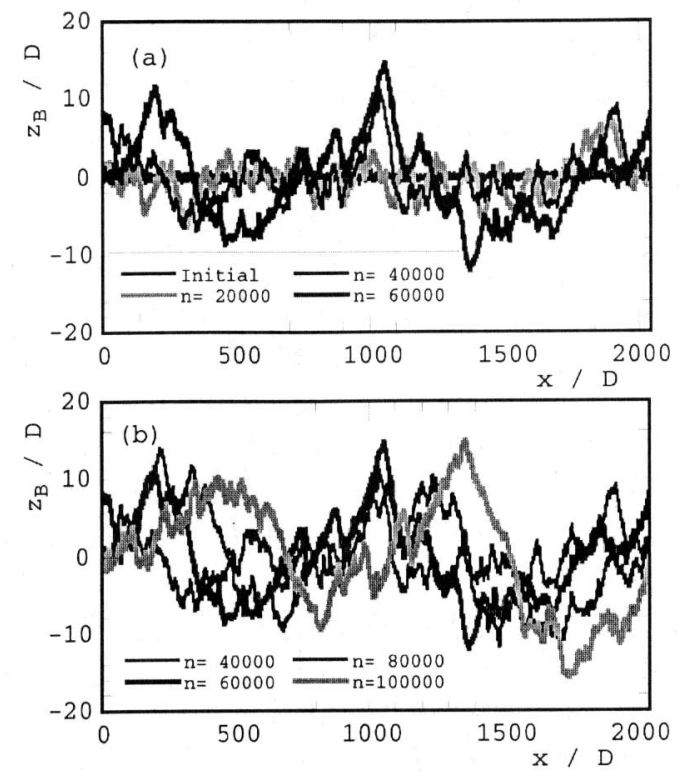

図-2 河床波の発達過程

全貌の理解が容易になる.

まず, 第一の過程は, 図-2(a)の $n=40000$ 程度まで の初期発達段階である.この段階においては, 初期条 件として与えられた平坦河床における粒径程度のラン ダムな微小凹凸が，土砂の離脱あるいは堆積の結果と して，その規模を増大させながら発達して行っている. 初期河床における離脱・堆積の生じ易さは, 図-3(a)を 見るとわかる通り場所的にほぼ均一である. しかし，局 所的に離脱あるいは堆積が生じやすい場所が存在して いることもわかる．これは，河床に見られる凹凸と密 接に関連しており, その後に成長・発達していく河床 波の “芽”に当たる部分である. 相対的な比較として， この段階では，河床上の凸部の上流側で堆積が生じや すく，下流側で離脱が生じやすい傾向がある。これは， 移動土砂粒子が河床上の凸部を乗り越えて移動を継続 することは容易ではないため, その上流側の登り斜面 上で運動を停止し, 堆積を起こす可能性が高いのに対 して，下流側の下り斜面では隣接する下流側粒子を乗 り越えて離脱することが上り斜面より容易であるため である.このように，河床上の凹凸の規模が小さく，流 れ場に組織的な変化がほとんど生じていない場合には, 河床上の凹凸という幾何学的条件に応じた重力の影響 が相対的に強く、これがそこで生じる土砂の運動さら には離脱・堆積にとって支配的な役割を果たしているこ とが推察される.さらに時間が経過すると、このよう な河床上の微小な凹凸の凹部にも堆積が生じるなどの 
理由から、これらの凹凸のうちの幾つかは合体し, や がてはまとまった規模の微小な波が連続して形成され るようになる. 例えば図-3(b) がこの段階に当たる.こ の段階で, ようやく離脱あるいは堆積の生じやすい場 所が偏在するようになる. このため, 土砂の堆積が生 じやすい場所を中心に河床上昇が進むことになり，こ れがその後に発達するより規模の大きな河床波の核と なる. 図-2(a) における $n=20000$ から 40000 までの過 程がこれに当たる. なお,この段階においても流れに 顕著な変化は見られない，また，河床波の流下方向へ の進行はほとんど見られず, わずかに上流側への移動 が見られる程度である。これは，前述の通り，河床の 凸部の上流側の上り斜面上で堆積が, 下流側の下り斜 面上で離脱がそれぞれ生じやすいという傾向と一致す るものである. 以上が初期発達過程の特徵である.

一方, これに続く第二の過程としては, 例えば図-2(b) の $n=60000$ 以降の過程がこれに当たる. この段階の 特徵は, 規模の増大とあわせて, 河床波の下流方向へ の移動にあるといえる. 図-2(b) における $n=80000$ か ら 100000 の間の変化を見ると, このことが理解できよ う.これは, 河床波の規模の増大に伴って, 流れ場に組 織的な変化が生じるようになり, 河床波と水面とが逆 位相となる特徵的な水面形になっているほか, 斜面に 沿うように上向き成分を持った流れあるいはその逆の 流れが生じている.このような流れ場の変化が土砂粒 子の離脱あるいは運動に与える影響は次第に無視でき ないものとなり, その結果, 離脱が生じる位置と堆積 が生じる位置とがはっきりと区分けされるようになる. このことは例えば図-3(d) を見るとわかりやすく, 河床 波の上流側斜面で浸食が，下流側斜面で堆積が生じる 傾向が見られる.このため, 河床波の下流側への移動 が引き起こされる．このように，河床上の凹凸がまと まりをなし，より規模の大きなものへと成長を遂げる 過程で, 河床の幾何学的形状に伴う重力の影響よりも, 流れ場の不均一性の影響の方が支配的となり, 砂泱や 砂堆として知られる規模の大きな河床波へと発達して いくものと推察される. なお, 流れ場に関して計算結 果を詳細に調べたところ, $n=100000$ の段階において も，これまでに報告されているような砂漸あるいは砂 堆上の流れほど顕著な剥離は生じていなかった.この 点の詳細に関しては, 紙面の関係上ここでは説明を省 略し, 今後の更なる検討をした上で別の機会に報告す ることにしたい.

次に, このような河床波の発達を, 全粒子平均のPickup rate $\overline{P_{s}^{\star}}$ と Step Length $\Lambda / D$ の時間変化という観点 から見てみることにしよう。これを調べたのが図-4で あり, 図の横軸が追跡した粒子個数 $n$ を表し, この值が 大きいほど時間が経過していることを表している.こ
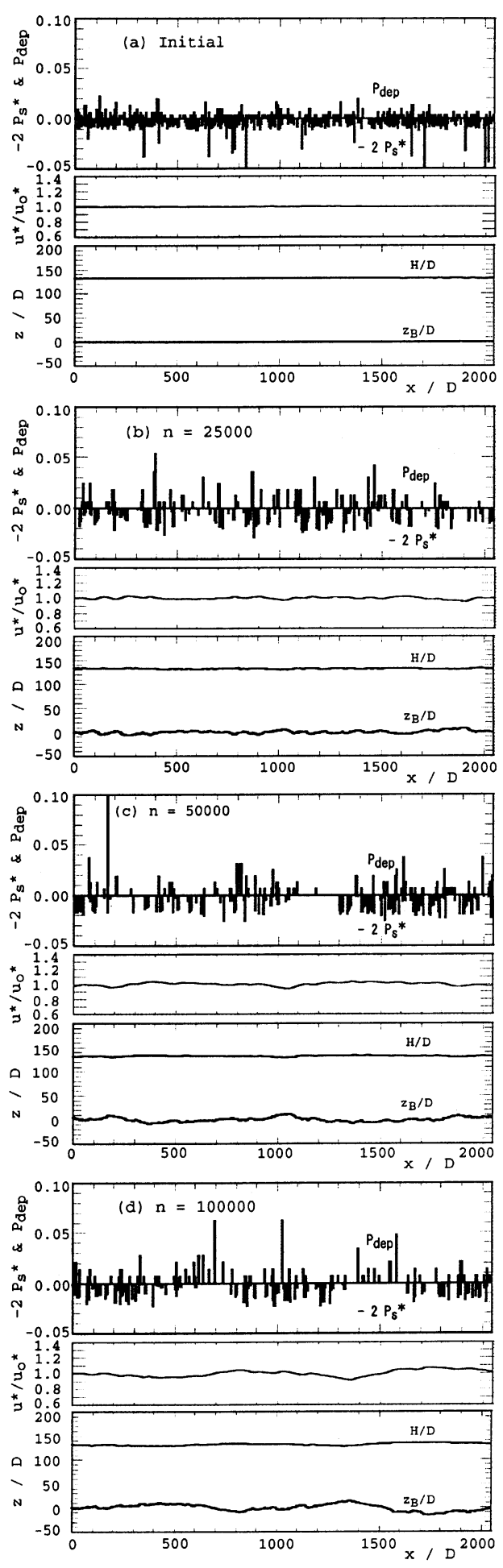

図-3 離脱率 $P_{s}^{\star}$ と堆積率 $P_{\text {dep }}$ の変化 


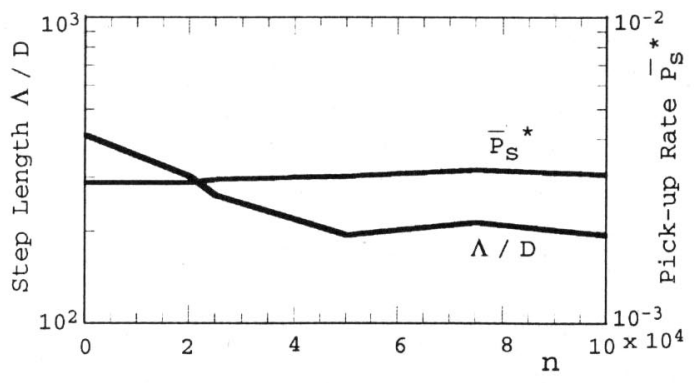

図-4 平均離脱率 $\overline{P_{s}^{\star}}$ と平均 Step Length $\Lambda / D$ の変化

こに, $\overline{P_{s}^{\star}}$ は, 前出の Rest period の平均值から式 (5) と 同様の方法で算出している. この図より, Pick-up rate は，前述の通り空間的には偏りを見せるものの，その 平均值としては時間的に大きく变化しないことがわか る. 一方, Step Lengthに関しては, 漸減しつつ一定值 に向かう傾向があることが見て取れる，後者に関して は，河床上の凹凸の規模の増大に伴い，これらの凹凸 が移動粒子の運動の継続にとって障害となり, 運動の 継続距離を低下させたものと考えている.

また, 解析モデルの検証のため, 初期状態として設 定した平坦河床上でのそれぞれの值について調べてみ ると, 従来から指摘されている值 ${ }^{11)}$ よりもわずかに大 きな值ではあるものの，概ね妥当な值の範囲内にある ことが理解された.さらに，このことと関連して，こ の解析モデルを用いた同様の数值計算を行うことによ り, 水理量ならびに土砂の粒径に态じた掃流砂量の算 定が可能であることも別途明らかになっている.この ことは, 土砂の離脱から停止に至る一連の運動を同一 の運動方程式に基づいて解析した結果として, いわゆ る掃流砂量式あるいは同曲線を導くことができる，と いう点で意義あるものと考えている，なお，これにつ いては別の機会に詳しく報告することとしたい．

さらに, 図-5には, 河床形状のフーリエ・スペクトル を示している. 図の横軸はそれぞれの規模の河床波の 波長を粒径で除した值を表している.この図より，ここ で形成されてきた河床波について見ると，初期におい ては様々な波長をもつ波の重ね合わせてあったものが， 次第に淘汰されて最終的には卓越波長が粒径の 1000 倍 程度の波にまとまっていくことが理解できる.

最後に, ここで形成された河床波の形状について, 従 来の知見との比較を試みる. なお，ここで設定した条 件は，Yalin ${ }^{12)}$ あるいは中川・辻本 ${ }^{13)}$ の区分図によれば 砂堆が形成される (ただし, 前者では, 砂漣と砂堆とが 共存するとされる領域にも近い) 領域に当たる.ささて， 前掲の計算例に関して, 最終状態における波長 $\lambda$ と波

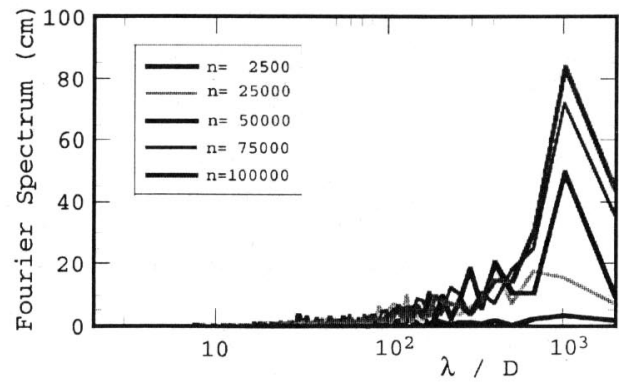

図-5 河床面のフーリエ・スペクトル

高 $\Delta$ とを求めると，概ね $\lambda=1000 D, \Delta=20 D$ 程度と

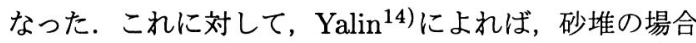
の波長は $660 D$ (砂鿰の場合は $(600-1000) D)$ であると され，その波高は $\Delta=h / 6 \times\left(1-\tau_{c}^{\star} / \tau^{\star}\right)=15 D$ 程度と される，一方，辻本 $\left.{ }^{11}\right)$ の図より波形勾配 $\Delta / \lambda$ を推定す ると 0.01 程度となり，本計算の結果である值 0.02 と極 端に大きな隔たりはない。このように，これらの既往 研究の成果と比較すると, 概略值としては妥当な結果 が得られたのではないかと判断している.なお，波長 に関しては，本解析で周期境界条件を用いているため, 想定している計算領域の規模がそこに形成される河床 波の波長を規定してしまっているのではないか，とい う疑問が生じるが，これに答えるために，計算領域の 規模を半分あるいは 3 倍にした検討もあわせて行った. その結果として，この検討の範囲内では，卓越波長は 概ね上記の值と一致することを確かめている。

\section{4. 結論}

本研究では, 個々の土砂粒子の運動の集積として, 河 床上の微小な凹凸が次第に組織立った微地形へと発達 し，やがては砂漣あるいは砂堆として知られる規模の 河床波一と成長していく過程を, 数值実験を通じて解 析することを試みた. 本研究の主な成果を以下に列挙 し，ここでの結論とする.

（1）個々の土砂粒子の運動の追跡を基礎とし，これに 流れ場の解析モデルをカップリングした新たな解 析モデルを構築した。 ここで提示した数值解析モ デルは，今後に向けての第一歩となるものである が，その主な特徵は，土砂粒子の運動に起因する いわゆる「流砂の非平衡性」の影響を力学的に陽 に反映できることにあり，この方法によれば，河 床変動計算などにおいてこれまで指摘されること の多かった「非平衡性」の問題を解消することに 繋がるのではないかと考えている. 
（2）土砂粒子の運動に着目した数值実験を通じて，よ り微視的な視点から河床波の形成過程を捉えるこ とができ, 形成機構に関わるいくつかの興味深い 知見が得られた。例えば, 砂漣や砂堆のような規 模を有する河床波が形成・発達していく過程には, 二つの素過程があり，前半の初期成長過程におい ては河床上の凹凸という幾何学的条件と重力の作 用が卓越するのに対して, 後半の発達過程におい ては流れ場との相互作用が重要となること，など がその特徵である．前者においては微地形の規模 が増大するだけであるのに対して，後者において は規模の増大とあわせて河床波自体が流下方向に 移動することが理解された。

（3）参考までに，本論文中に示した解析結果を，砂泱 あるいは砂堆の形状特性に関する従来の知見と比 較したところ，砂堆の形状と比較的近い值をとる ことがわかった．ただし，解析モデルの検証とい う観点から言うならば，厳密にはさらに多くの条 件下で同様の解析を行う必要がある.

今後は, 上記の点とあわせて, 本研究で近似的あるい は簡易的な取り扱いをした部分について，さらに検討 を加えていく予定である.

謝辞: 本研究の一部は, 著者の早稲田大学特別研究期間 中に滞在先の University of Minnesota で行われた. 公 私にわたりお世話を戴き，また貴重なコメントを賜った Gary Parker 教授に深甚の謝意を表します．また，本研 究は早稲田大学特定課題研究助成を受けて行われたこ とを記します。

\section{参考文献}

1) 吉川秀夫編: 流砂の水理学, 第 5 章, 1986 .

2) Kennedy, J. F.: The Mechanics of dunes and antidunes in erodible-bed channels, Journal of Fluid $\mathrm{Me}$ chanics, Vol. 16, Part.4, pp.521-554, 1963.

3）懀谷 治, 道上正規: 砂堆の発生・発達に関する数值解 析, 土木学会第 51 回年次学術講演会論文集, pp.630-631, 1996.

4) Nakagawa, H. and Tsujimoto, T.: Sand bed instability due to bed load motion, Proc. ASCE, Vol.106, HY12, pp.2029-2051, 1980.

5）関根正人，浅田 宗: 土砂粒子スケールの運動から見た 河床上微地形の形成過程に関する研究，土木学会第 51 回年次学術講演会概要集, pp.552-553, 1996.

6）関根正人，北川禎之：土砂粒子の運動の解析に基づく河 床波の形成過程に関する研究，土木学会第 52 回年次学 術講演会概要集, pp.436-437, 1997.

7）関根正人, 吉川秀夫: 掃流砂の流送機構に関寸る研究, 土木学会論文集, 第 351 号/II-2, pp.69-75, 1984.

8）関根正人, 吉川秀夫: 掃流砂の停止機構に関する研究, 土木学会論文集, 第 399 号/II-10, pp.105-112， 1988.

9) Sekine, M. and Kikkawa, H.: Mechanics of saltating grains, Journal of Hydraulic Engineering, ASCE, Vol.118, No.4, pp.536-558, 1992.

10）矢部 孝，観山正見，椛島成治: パソコンによるシミュ レーション物理, 朝倉書店, 1992 .

11）中川博次, 辻本哲郎: 移動床流れの水理, 技報堂出版, 1986.

12) Yalin, M. S.: Mechanics of Sediment Transport, pp.209-267, 1977.

13) Nakagawa, H. and Tsujimoto, T.: Lag behavior of unsteady flow with sand dunes, Proc. 2nd. Int'l Symp. on River Sedimentation, Nanjing, China, pp.173-186, 1983.

14) Yalin, M. S.: Geometrical properties of sand waves, Proc. ASCE, Vol.90, HY5, pp.105-119, 1964.

(2000. 11. 7 受付)

\title{
NEW ATTEMPT OF NUMERICAL SIMULATION OF SAND WAVE FORMATION BASED ON THE ANALYSIS OF SEDIMENT PARTICLE MOTION
}

\author{
Masato SEKINE
}

Numerical simulation of sand wave formation was conducted in the present paper. Saltation model was extended in order to accomplish this simulation. One of the all bed particles which expose on the surface is checked up arbitraly whether it can be picked up and make an incipient motion or not. And its trajectory is traced every time step until it ceases its motion and rests on the bed. Time variation of flow velocity field over the bed surface is also evaluated simultaneously in order to reflect the effect of bed evolution. In the present model, any turbulence models were not introduced for simplicity to understand the mechanism of this formation process more easily and the space in future work is still left open. 